POLLACK PERIODICA

An International Journal for Engineering and Information Sciences

DOI: $10.1556 / 606.2017 .12 .1 .1$

Vol. 12, No. 1, pp. 3-15 (2017)

www.akademiai.com

\title{
HYDROLOGIC MODELING OF THE LOESS BLUFF IN DUNAUJVAROS, HUNGARY
}

\author{
${ }^{1}$ Gergő MURINKÓ, ${ }^{2}$ Katalin BENE \\ Department of Transport Infrastructure, Széchenyi István University \\ Egyetem tér 1, 9026 Györ, Hungary \\ e-mail: ${ }^{1}$ murinko.gergo@gmail.com, ${ }^{2}$ benekati@sze.hu
}

Received 1 January 2016; accepted 18 October 2016

\begin{abstract}
The western shoreline of the Danube from Érd to Mohács consists of loess bluffs up to $50 \mathrm{~m}$ high. These bluffs can be susceptible to landslides when groundwater conditions weaken the supporting loess. Often this will occur during periods of high rainfall, however morphological, geological and other factors are also important in triggering these movements.

Changes in pore water pressures related to precipitation, confined water levels driven by remote catchments, and river level fluctuations are widely recognized as important factors controlling the loess bank stability. This work aims to determine the interaction of rainfall, river level, drainage and local pumping on the pore pressure regime and stability of the bluffs.

As a first step, a realistic 2-dimensional infiltration and groundwater model was built that reflects the influence of river levels, rainfall patterns, and local pumping. Based on model results, initial and boundary conditions have a strong influence on seasonal pore pressures. Further study will better define those influences on slope stability along the bluffs.
\end{abstract}

Keywords: Loess, Bluff, Landslide, Hydrology model, Hydrus

\section{Introduction}

The western shoreline of the Hungarian Danube, from Érd to Mohács consists of steep bluffs, sometimes $50 \mathrm{~m}$ high (Fig. 1). Landslides occur frequently and the bluffs along the river have retreated continuously. The bluffs are composed of loess, destabilized by inundation due to heavy rainfall on the land side and flooding, recession and piping; or bank cutting by the Danube. Much of the bluff is quite stable, sustaining a vertical face over decades, however other areas are less stable and many areas reactivate over time, causing damage to buildings, roads, railroads and infrastructure. In 
the last fifty years, several solutions have been attempted to prevent subsequent movements. Some of these solutions require enormous amounts of earthwork while others have a marked impact on local groundwater levels.
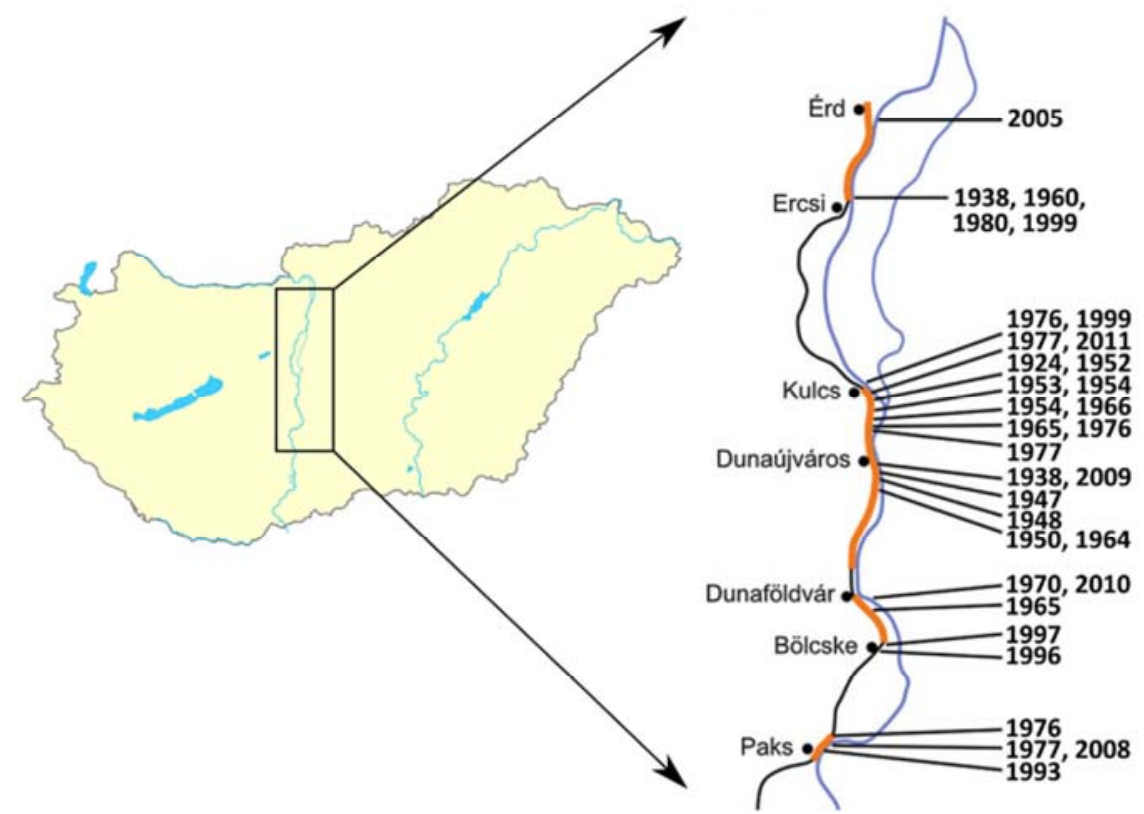

Fig. 1. Bluffs and slope failures along the Danube River, southward to Paks (sources: [1], [2], modified by the Authors)

\subsection{Previous research}

Research on the causes and mechanics of bluff instability have continued with some success over the past 50 years. Investigators have found correlations between the accumulated precipitation and the initiation or reactivation of landslides [3]. Others have considered water levels in the Danube a more important contributor [4], [5], [6]. Both of these phenomena have a profound effect on the local groundwater regime and require consideration when constructing a comprehensive model of pore pressures in the loess bluffs and the soils beneath them [2], [7], [8].

Research by $\mathrm{Tu}$ et al. [9] showed that water infiltration rate and depth (without any cracks or fissures) are influenced more by long-term continuous light rains rather than short-term heavy ones. Therefore, deep-seated landslides are more likely caused by long-term rainfall. However, study of historical landslide events has shown that shortterm wet periods following a prolonged dry season have also caused movement. Other researchers [10] have found slopes composed of homogeneous soils with a low saturated coefficient of permeability $\left(k_{s}<10^{-6} \mathrm{~m} / \mathrm{s}\right)$ are safe from short-term rainfalls, but are still susceptible to instability if there has been enough antecedent rainfall. 


\subsection{The focus of the research}

The research focused on a possible set of progressive steps that contribute to movement of the entire bluff. Careful measurement of slope movement in Dunaszekcső [11], [12] would indicate that the initial phase of movement may be a series of smaller movements, which then lead to a more general and catastrophic failure. While the study illustrated movement of various sections of the slope over time, the underlying mechanics and analyses are still difficult to quantify. This is not surprising since the stability of loess bluffs are indeed complex and involve many factors whose influence are nearly impossible to separate.

The possibility that the bluff system fails progressively by two ongoing processes was examined:

(1) In the upper reaches of the bluff, blocks of loess separate from their parent structure due to infiltrating water that exits preferentially above paleosol/low conductivity strata. The paleosols are softened and some piping erosion may occur directly above them. As the blocks are weakened at their base, tensile stresses increase, causing thin (perhaps unnoticed) vertical cracks to form. Once the cracks form, greater vertical flow occurs and the process becomes more damaging. This observation was confirmed by other researchers in other loess areas [13];

(2) At the same time scale, the lower reach of the bluff is inundated by high river levels then subjected to 'drawdown' as the river recedes; with saturated soil and no contribution of buoyancy from the river. Further drainage of the lower bluff will generate piping zones as well.

Before a complex set of events can be analyzed, the infiltration of water and its movement through the soil must first be studied. This paper discusses our initial effort to model movement.

Several questions arose during the study:

(1) Can adequately define the initial conditions? The process is continuous and should be modeled for a number of years to reach a reasonable cyclic equilibrium;

(2) How does the presence of paleosols affect the flow/pore pressure regime of the infiltrating water within the loess? Can it de-stabilize the upper loess and generate enough tensile stress to cause extension cracks;

(3) Does the debris at the toe of the bluff have an influence on where groundwater will exit the slope? Does it act to block water movement between the bluff and the river or does the river fully control exit head levels;

(4) Does soil anisotropy affect flow/pore pressure? Is it enough to have a significant influence on stability;

(5) How does the interaction between rainfall infiltration and river level fluctuation impact groundwater flow and pore pressures? What sorts of 'lag-times' are characteristic for pore pressure generation within the bluff due to infiltrating rainfall and due to fluctuation in river levels? 
Flow and pore pressures are intimately linked in our considerations since increased pore pressures reduce soil strengths. High flow or high gradients may induce piping erosion, generating (thin) zones of reduced strength. Additionally, if there is vertical, or nearly vertical fracturing, preferential flow will occur, significantly concentrating vertical flow paths and encouraging deeper fractures and block sliding. The analysis is challenging due to the generation of vertical fissures and relatively thin, weakened zones. Limit equilibrium and finite element analyses become more difficult to perform. Since the slopes failures are activated over short times, the generation of groundwater flow and pore pressures are transient as well.

The first effort focuses primarily on initial and boundary conditions, and the evaluation of infiltration from precipitation. Due to the unsaturated conditions at the top of the slope, an unsaturated flow model was constructed and analyzed using Hydrus software.

\section{Study area}

Dunaujvaros is located south of Budapest on the western shore of the Danube (Fig. 2). With the plateau situated at 145 meters above the Baltic Sea level (m a.s.l.), the shoreline bluff is 50-60 m above the level of the Danube. In the autumn of 1964, a landslide occurred; the scarp extended $1300 \mathrm{~m}$ parallel to the river and $15-20 \mathrm{~m}$ behind the bluff line [8]. An extensive soil exploration program was carried out after the landslide.

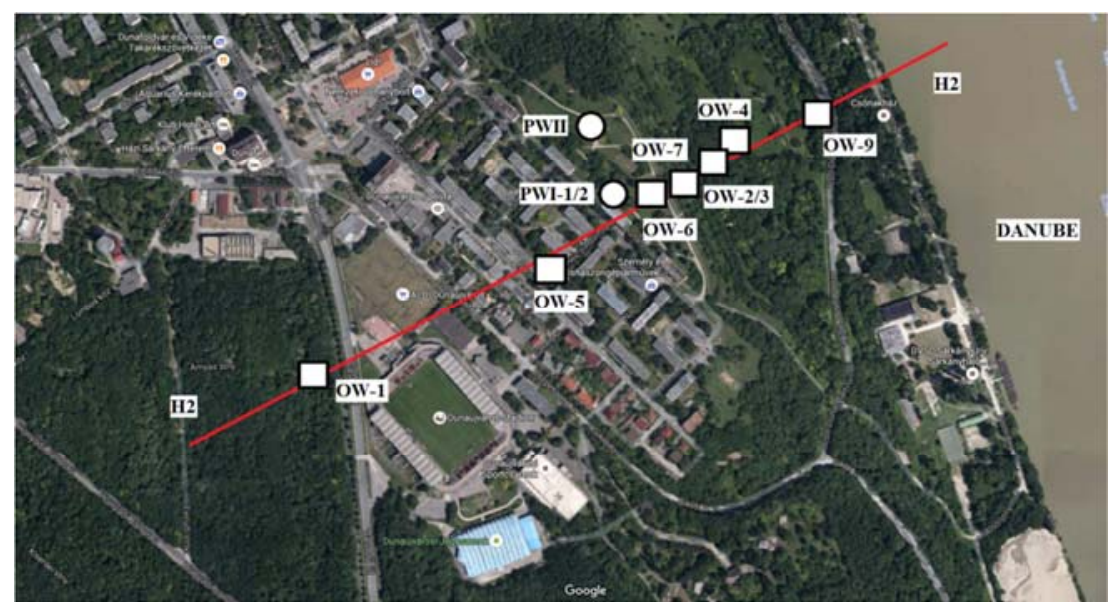

Fig. 2. Overview of Dunaujvaros showing soil borings, observation wells, pumping wells and $\mathrm{H} 2$ profile line

\subsection{Geological-geotechnical conditions}

The loess is 30-50 $\mathrm{m}$ thick in this area (Fig. 3), but it is not at all homogeneous with varieties of fine sand, silt, red clay and thin, random sand layers. The upper section is 
yellow, unsaturated, young loess becoming less permeable silt and clay in the lower section. The Pleistocene loess above the groundwater has a macro-porous structure with definite anisotropy which influences permeability. Generally, the vertical permeability is much larger than the horizontal one, because the vertical roots of dead plants left channels lined by $\mathrm{CaCO}_{3}[8]$.

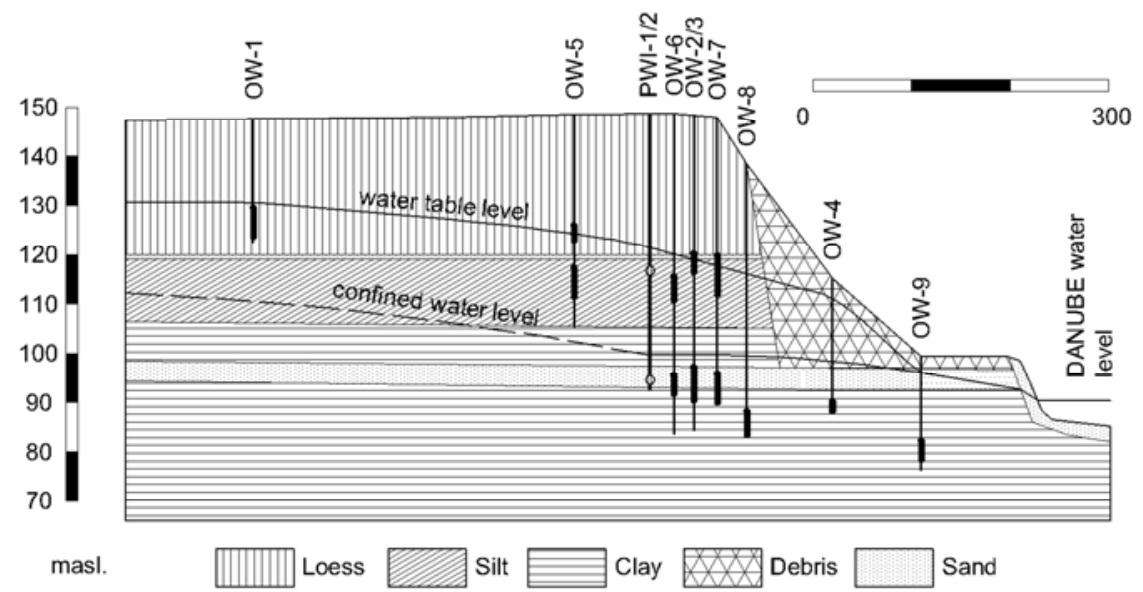

Fig. 3. H2-H2 cross section with observation wells with piezometric heads [sources: after Gy. Scheuer [14] and Á. Kézdi [8] modified by the Authors and supplemented with more data]

The groundwater level is about 115-130 ma.s.l., situated over the lower, less permeable layers in the high bank. The border of the Pannonian Clay strata is between 91-101 m a.s.1. at the high bank. This layer is $\sim 110 \mathrm{~m}$ a.s.l. along the western border of the city. The previous field exploration [8], [14] verified that most strata were nearly horizontally bedded with a slight inclination east to west i.e. dipping toward the river. The upper sand layers within the Pannonian strata are connected and clearly detectable in the borings. There are six separate confined aquifers, with 2-5 m thickness with high permeability. Earlier chemical investigations [14] revealed that the unconfined region mixes only with the first confined sand layer and the debris material. The uppermost confined sand stratum was considered while deeper ones were neglected in this preliminary study. Field investigations found no trace of a larger, causative fault. During the remediation work many dewatering structures were built in the bluff. For example, two large diameter caisson pumping wells (PW-I, PW-II) remove water from the loess at approximately $116 \mathrm{~m}$ a.s.l. and from the sand at approximately 94 m a.s.1. [15].

In Fig. 2 the white circles indicate caissons in the unconfined and confined layers and the squares are observation wells. Typical soil and water profiles were selected following the former H2-H2 cross-section [14]. The $1000 \mathrm{~m}$ long profile is shown in Fig. 3, and the vertical scale exaggeration is 5:1. 


\subsection{Hydrological measurements}

In this study, monthly rainfall records were obtained, more or less weekly groundwater levels and daily river levels from 1996 to 2007 at Dunaujvaros. Groundwater levels were available from wells OW-1, OW-2, OW-3, OW-4, OW-5, OW-6, OW-7, OW-8 and OW-9. The location of the wells, general groundwater level, and the piezometric heads are shown in Fig. 2 and Fig. 3.

Monthly precipitation (Fig. 4) shows seasonal cycles that are typical for Hungary. Average annual rainfall is about $600 \mathrm{~mm}$ with a very slight decrease over time. The river stages (Fig. 5) for the same period show a slightly declining trend as well. The pumping station in the caissons have worked continuously with an average discharge of $350 \mathrm{~m}^{3} /$ day (PWI-1) from the Pannonian sand level and $35 \mathrm{~m}^{3} /$ day (PWI-2) from the upper level of the loess formation.

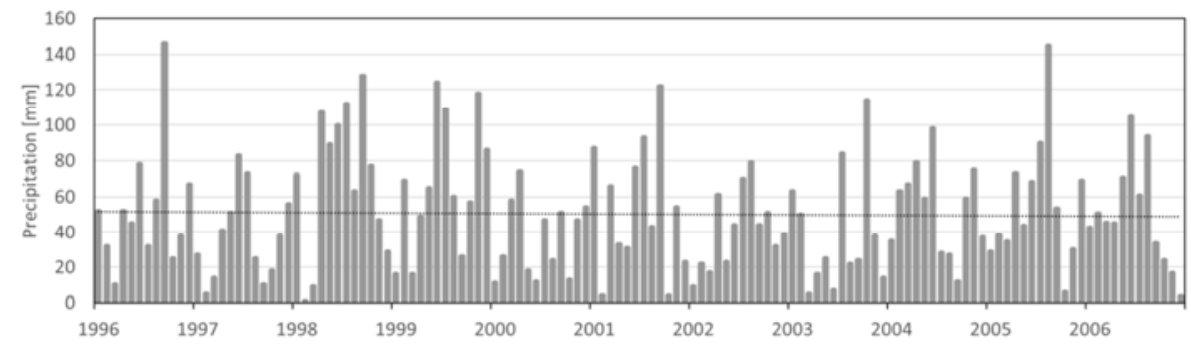

Fig. 4. Monthly precipitation data

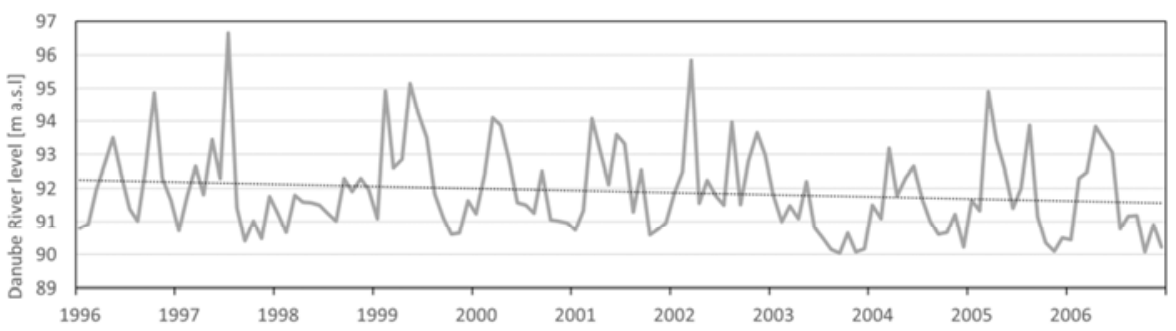

Fig. 5. Daily Danube River level

\section{Hydrologic model development}

\subsection{Conceptual model}

The preliminary model is two-dimensional; however a 3-D model may be necessary later due to the influence of the pumping wells. As it is shown in Fig. 6, soil and boundary conditions are simplified to allow for the initial assessment of groundwater movement. 


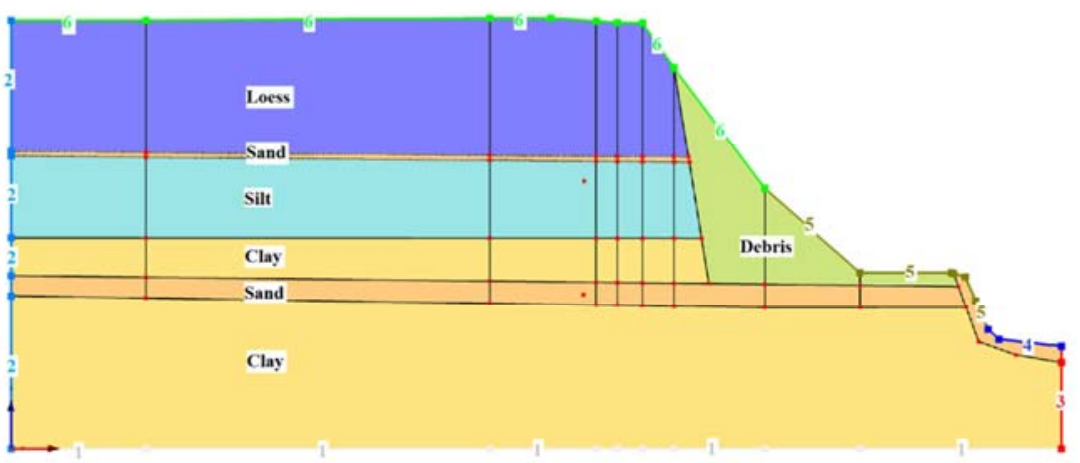

Fig. 6. Conceptual model showing boundary conditions and soil layers

Due to the highly nonlinear conductivity properties of unsaturated soils, much of the initial modeling was focused on attaining a stable and satisfactory flow (and head) regime. Five different soil types were used in the model: Loess, Silt, Debris, Sand and Clay. Six different boundary conditions were used: 1-No flux; 2-time variable (remote catchment); 3-constants head; 4-time variable (Danube); 5-seepage face; 6-atmospheric.

\subsection{Soil properties}

Since there was only soil index data available, hydraulic conductivity values came from the literature [14], [16]. The fitting parameters of van Genuchten [17] were applied to soil grain-size distribution and the bulk density data using software built into Hydrus (Rosetta Lite v. 1.1. [18]). These parameters were used only as initial estimates because previous researchers [19] found that class averages provide poor representation of conductivity in soils. Variations of unsaturated behavior within certain classes may exceed the difference in averages between classes. The water content, $\theta\left[\mathrm{m}^{3} / \mathrm{m}^{3}\right]$, and hydraulic conductivity, $K[\mathrm{~m} / \mathrm{s}]$, are highly non-linear functions of pore water pressure head, $\psi[\mathrm{m}]$. For unsaturated conditions $\psi$ is negative i.e. matric suction. The van Geuchten equation was used relate $\theta(\psi)$ and $K(\psi)$, to $\psi$ for the different soils.

Effective saturation, $S_{e}[-]$, is defined as:

$$
S_{e}=\frac{\theta(\psi)-\theta_{r}}{\theta_{s}-\theta_{r}}
$$

where $\theta(\psi)$ is given by:

$$
\begin{array}{ll}
\theta(\psi)=\frac{\theta_{S}-\theta_{r}}{\left(1+\left.\alpha \psi\right|^{n}\right)^{1-1 / n}}+\theta_{r}, & \psi<0, \\
\theta(\psi)=\theta_{S}, & \psi>0,
\end{array}
$$


where $\theta_{s}$ is the saturated moisture content; $\theta_{r}$ is the residual moisture content; and $\alpha[1 / \mathrm{m}]$ and $n[-]$ are empirical fitting parameters. For hydraulic conductivity, the Mualem-van Genuchten [20] equation faithfully models the rapid decrease in conductivity with increased suction and reduced moisture (saturation):

$$
\begin{array}{ll}
K(\psi)=K_{s} S_{e}^{1 / 2}\left[1-\left(1-S_{e}^{1 /(1-1 / n)}\right)^{1-1 / n}\right]^{2}, & \psi<0, \\
K(\psi)=K_{s}, & \psi \geq 0 .
\end{array}
$$

Typical $\theta(\psi)$ vs. $\psi$ curves are shown in Fig. 7. Saturated or nearly saturated conditions correspond to low matric suction levels. As the soil becomes drier, suction levels increase. The suction increase generates higher confinement stress and greater shear strength in the soil. So, as the soil dries, the bluff becomes more stable. As the soil becomes saturated, the matric suction reduces, shear strength is lost, and the bluff is less stable. If the soil becomes very dry; where matric suction no longer draws together a connected framework of particles, then the benefit of matric suction is lost, and the bluff is less stable. Therefore, understanding the relationship between soil moisture, soil strength, and bluff stability is very important.

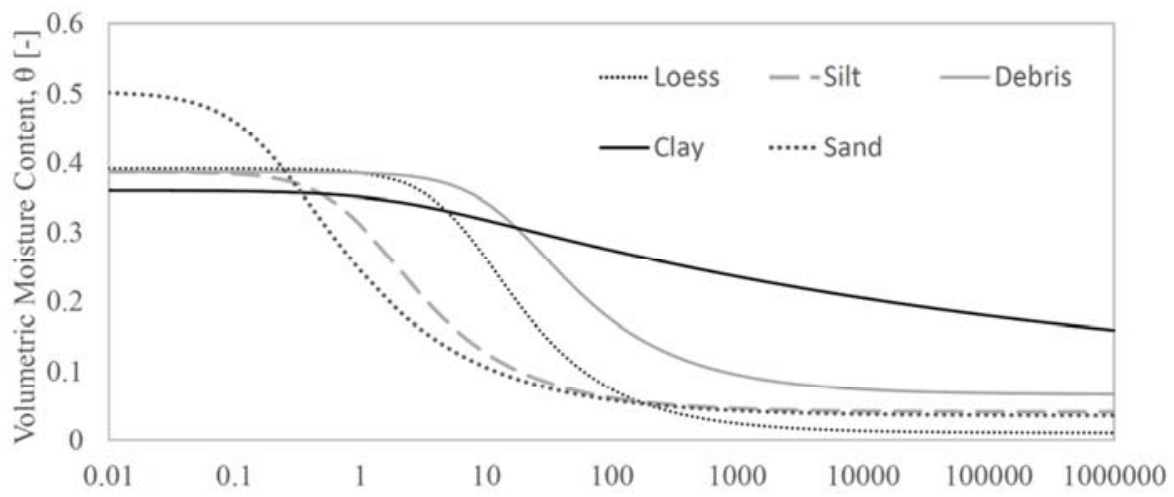

Fig. 7. Soil water content curves

The initial soil properties were modified during the validation phase. The modified soil parameters are shown in Table $I$.

Changes in conductivity due to saturation level are also important. Lower saturation levels mean much lower conductivities and slower water movement. This will significantly change how pore pressures (or suctions) are distributed throughout the bluff. Dissolution of cementation between loess particles, formation of preferential flow paths, piping erosion, and response to boundary influences (river level fluctuations, catchment inflow, rainfall infiltration) would be affected by changes in conductivity as well. 
Table I

Soil parameters used in the hydrologic model

\begin{tabular}{|c|c|c|c|c|c|c|c|}
\hline \multirow{2}{*}{ Soil } & $\theta_{r}[-]$ & $\theta_{s}[-]$ & \multirow{2}{*}{ Alpha [1/m] } & $n[-]$ & $1[-]$ & \multicolumn{2}{|c|}{ Hyd Conductivity [m/s] } \\
\cline { 6 - 8 } & & & & & & vertical & horizontal \\
\hline Loess & 0.0104 & 0.3917 & 0.143 & 1.67 & 0.5 & $1.3 \mathrm{E}-05$ & $4.5 \mathrm{E}-07$ \\
Silt & 0.0408 & 0.387 & 0.95 & 1.6163 & 0.5 & $1.1 \mathrm{E}-07$ & $1.1 \mathrm{E}-07$ \\
Debris & 0.0662 & 0.3869 & 0.064 & 1.5787 & 0.5 & $1.0 \mathrm{E}-07$ & $1.0 \mathrm{E}-07$ \\
Clay & 0.07 & 0.36 & 0.5 & 1.09 & 0.5 & $5.6 \mathrm{E}-09$ & $5.6 \mathrm{E}-09$ \\
Sand & 0.0354 & 0.5037 & 4.96 & 1.4851 & 0.5 & $4.6 \mathrm{E}-05$ & $4.6 \mathrm{E}-05$ \\
\hline
\end{tabular}

\subsection{Numerical model-Hydrus}

Hydrus 2.04 [18] finite element software was selected for modeling. The Hydrus 2D program solves the 2 dimensional Richards' equation for unsaturated flow.

$$
\frac{\partial}{\partial x}\left[K_{x}(\psi) \frac{\partial \psi}{\partial x}\right]+\frac{\partial}{\partial z}\left[K_{z}(\psi) \frac{\partial \psi}{\partial z}+1\right]=\frac{\partial \theta(\psi)}{\partial t}
$$

where $x, z[\mathrm{~m}]$ are the coordinate axes; $t[\mathrm{~s}]$ is time; $\psi[\mathrm{m}]$ is the pore water pressure head; $\theta\left[\mathrm{m}^{3} / \mathrm{m}^{3}\right]$ is the volumetric water content; and $K_{x}$, and $K_{z}[\mathrm{~m} / \mathrm{s}]$ are the hydraulic conductivities in the $x$, and $z$ directions. The software uses a time-marching algorithm to solve Equation 4 by iteration for pore pressure head at each successive time step. The iteration is necessary due to the highly nonlinear behavior of $K_{x}$ and $K_{z}$.

Hydrus is very robust program since it can model abrupt changes in hydraulic conductivity and moisture content. However, there is a necessary balance between accuracy of pressure and moisture conditions throughout the domain, computational stability, and duration of calculations. For 2-D models, with moderate element discretization (for example 1000 nodes/elements) and a hundred time steps, solutions time is 5-30 minutes on a modern laptop. As the complexity of materials, number of degrees of freedom, analysis duration and boundary conditions increase, solution times can reach 1-2 hours. For 3-D problems, a multi-CPU workstation is required.

\subsection{Geometry, mesh and domain properties}

Model dimensions are $82 \mathrm{~m}$ x $1000 \mathrm{~m}$ with the soil layering are shown in Fig. 6. Length and time units were meters and days respectively. The model is composed of triangular second-order elements. Sensitivity analyses were performed to determinate optimum dimensions for the grid. The sizes of the elements are $8 \mathrm{~m}$ and refined locally near the seepage face and next to the pumping well screen. Smaller sizes would have required reduced time increments, increasing the number of computation steps as well as the size of the transmission matrix. A reduction to half the element length translates 
roughly to an increase in solution time by a factor of eight. The base time increment was set to 30 days with the entire analysis lasting up to 10 years.

\subsection{Boundary conditions}

Boundary conditions have a profound influence on the overall model behavior. A great deal of effort was spent on investigating their influence on the pore pressures within the bluff. Fig. 6 shows several of the applied boundary conditions. The ground surface is subject to atmospheric conditions where precipitation infiltrates according to the data from Fig. 4. The slope face is designated a seepage face boundary condition. If the seepage face is saturated, it is treated as a pressure head boundary with $h=0$. If the face is not saturated, it becomes atmospheric boundary condition. This boundary condition allows water to freely exit the face if there is positive head at that location. The fluctuating water level in the river, obtained from Fig. 5 was modeled by using a time-variable head boundary condition as shown in Fig. 6. Similar boundary conditions were applied to represent land-side variable groundwater levels. Zero flux boundary conditions were defined for the bottom boundaries. In order to simulate well pumping, a discharge value was estimated using the Darcy-Dupuit-Theim equation for confined aquifers and a well gallery [21, pp. 44-45]. The well was modeled as a negative recharge from a single node.

\subsection{Initial conditions}

Initial conditions were applied in two stages. The first calculation stage was solved with constant head conditions on the landward side based on average well readings over ten years. Constant head conditions were set on the river side with an average low river level. The model was run for a ten-year period (120 time steps) with no applied precipitation in order to achieve steady state moisture distribution. The output from the steady state run was used as initial conditions for the time-varying modelling step.

\section{Model validation with field measurement}

The model was validated by comparing predicted and measured head levels in three observation wells. The wells are located in Fig 2, OW-1 is toward the land-side, $\mathrm{OW}-2 / 3$ in the center, and $\mathrm{OW}-4$ near the river-side. In OW-2/3 there are two well screens; one in the unconfined (OW-2) layer and the second in the confined (OW-3) layer below.

Fig. 8 compares predicted and measured head levels in OW-1. Field measurements are indicated by black circles and model predictions by gray triangles. The general downward trend in predicted levels was achieved by increasing vertical conductivity in the loess. The general trends agree, however the influence of pumping (in 1998 and 2003) may have caused greater disagreement between predicted and measured values. Additional study will be directed toward evaluating the pumping effects more thoroughly. 


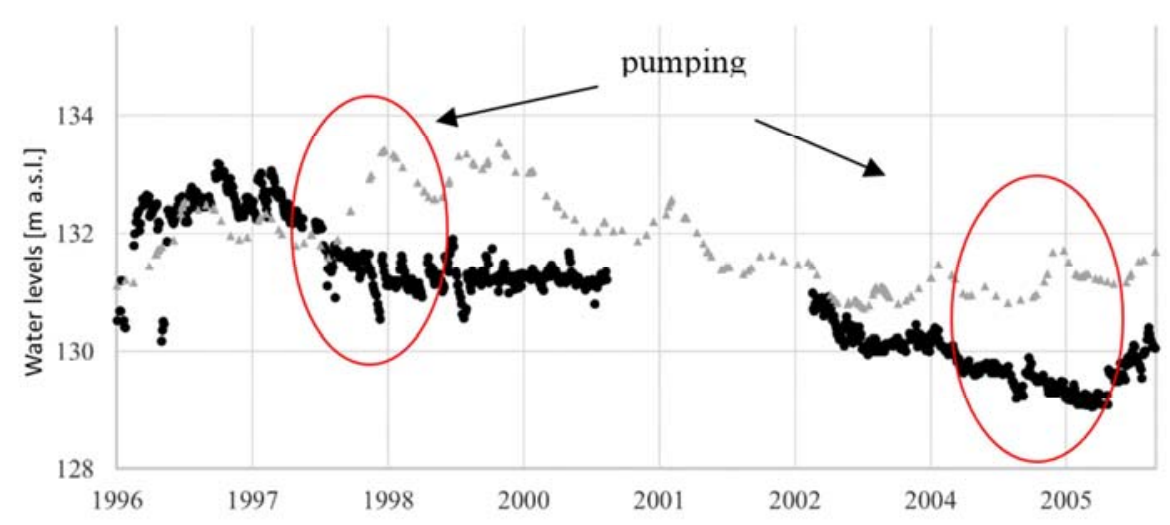

Fig. 8. • OW-1 field measurement and $\triangle$ Hydrus result

Fig. 9 presents predicted and measured water levels from OW 2/3. Good agreement can be found for both the unconfined (black circle) as well as the confined (dark gray circle) well screens. While some of the smaller fluctuations remain difficult to capture, the average levels and longer term trends are encouraging. The results of the riverside well (OW-4) are also in general agreement. However, the model response seems to be slower than actual conditions.

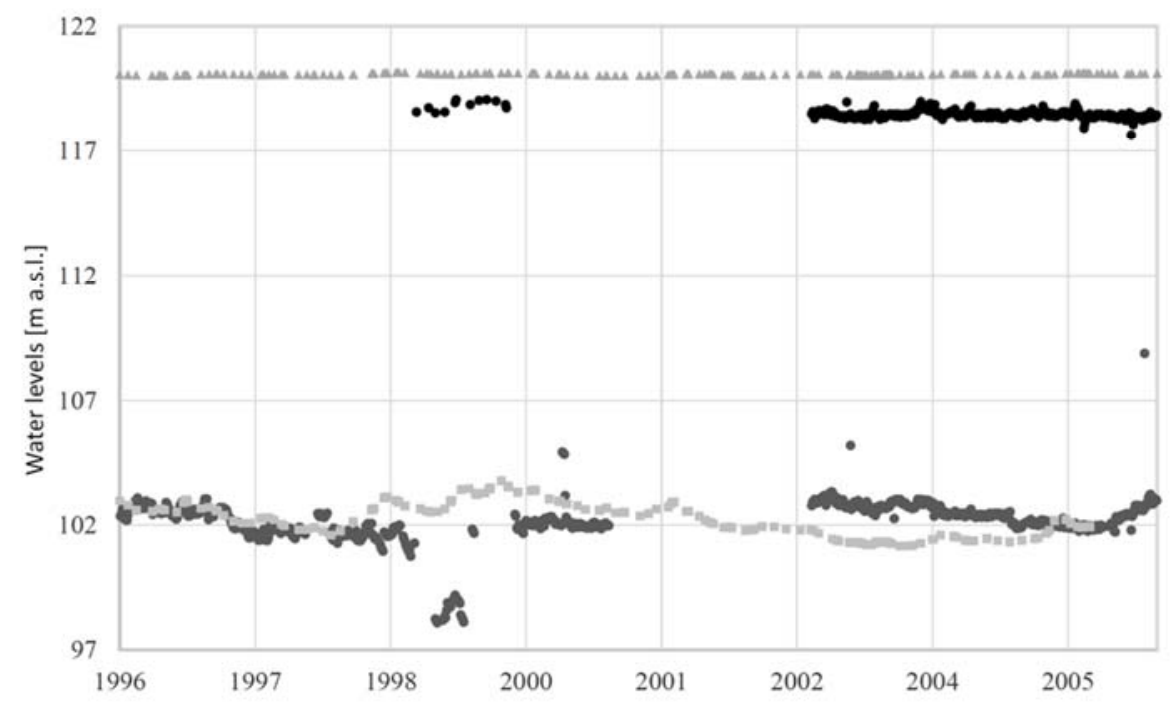

Fig. 9. • OW-2 field measurement compared with $\Delta$ Hydrus result, and $\bullet$ OW-3 field measurement compared with $=$ Hydrus result 


\section{Conclusions}

The Authors have demonstrated the usefulness of developing a comprehensive groundwater model to predict pore pressure changes in the Dunaujvaros bluff system. The model can successfully reproduce surface infiltration, land-side catchment seepage, river-side channel fluctuations and dewatering within the bluff system itself. Using this as a start, further study of the effective stress conditions and stability within the bluff will be possible.

Based on the modeling results, the fluctuations in river levels contribute to a more rapid change in moisture and pore pressure, while the landward catchment and surface infiltration may drive a longer-term moisture regime. Determination of their interaction and the influence of well pumping will the next step in the study. Finally, the application of the pore pressure changes to assess bluff strength and stability will continue to be the focus of our research.

\section{Acknowledgement}

The Authors are grateful to the Bank-protection company of Dunaujvaros who contributed useful information and advice for this paper. Most of data and the measurements for this paper were supported by them.

\section{References}

[1] Kleb B., Schweitzer F. Assessment of the impact of landslide prone high banks on urban environment along the River Danube, (in Hungarian) in: Ádám A., Meskó A. (Eds), Földtudományok és a földi folyamatok kockázati tényezöi, Budapest, Hungarian Academy of Sciences, 2001, pp. 169-193.

[2] Kovács I. P., Fábián S. Á., Radvánszky B., Varga G. Dunaszekcső castle hill, landslides along the Danubian loess bluff, in: Landscapes and Landforms of Hungary, Springer, 2015, pp. 113-120.

[3] Juhász Á. The role of climatic effects on the development of high banks (in Hungarian) Földtani Kutatás, Vol. XXXVI, No. 3, 1999, pp. 14-20.

[4] Domján J. Bluff landslides at Middle-Danube area (in Hungarian) Hidrológiai Közlöny, Vol. 32, 1952, pp. 416-423.

[5] Galli L. Laws of the stability of the bluffs of the Danube and the Balaton (in Hungarian) Hidrológiai Közlöny, Vol. 32, No. 11-12, 1952, pp. 409-415.

[6] Horváth Zs., Scheuer Gy. Engineering geological analysis of the Dunaföldvár landslide (in Hungarian) Földtani Közlöny, Vol. 106, 1976, pp. 425-440.

[7] Pécsi M., Schweitzer F., Scheuer Gy. Engineering geological and geomorphological investigations of landslides in the loess bluffs along the Danube in the Great Hungarian Plain, Acta Geologica Hungarica, Vol. 22, 1979, pp. 327-343.

[8] Kézdi Á. Landslide in Dunaujvaros (in Hungarian) Mélyépítéstudományi Szemle, Vol. XX, No. 7, 1970, pp. 281-297.

[9] Tu X. B., Kwong A. K. L., Dai F. C., Tham L. G., Min H. Field monitoring of rainfall infiltration in a loess slope and analysis of failure mechanism of rainfall-induced landslides, Engineering Geology, Vol. 105, No. 1-2, 2009, pp. 134-150. 
[10] Rahardjo H., Ong T. H., Rezaur R. B., Leong E. C. Factors controlling instability of homogeneous soil slopes under rainfall, Journal of Geotechnical and Geoenvironmental Engineering, ASCE, Vol. 133, 2007, pp. 1532-1543.

[11] Újvári G., Mentes Gy., Bányai L., Kraft J., Gyimóthy A., Kovács J. Evolution of a bank failure along the River Danube at Dunaszekcső, Hungary, Geomorphology, Vol. 109, No. 3-4, 2009, pp. 197-209.

[12] Bányai L., Mentes Gy., Újvári G., Kovács M., Czap Z., Gribovszki K., Papp G. Recurrent land-sliding of a high bank at Dunaszekcső, Hungary: geodetic deformation monitoring and finite element modeling, Geomorphology, Vol. 210, 2014, pp. 1-13.

[13] Zhuang J., Peng J. A coupled slope cutting - a prolonged rainfall-induced loess landslide: a 17 October 2011 case study, Bull Eng Geol Environ, Vol. 73, No. 4, 2014, pp. 997-1011.

[14] Karácsonyi S., Scheuer Gy. Hydrological observation in the area of Dunaujvaros (in Hungarian) Hidrológiai Közlöny, Vol. 49, No. 3, 1969, pp. 115-126.

[15] Andai P. The rehabilitation of the bank of Dunaujvaros (in Hungarian) Mélyépítéstudományi Szemle, Vol. XX, No. 7, 1970, pp. 298-312.

[16] Donoval K., Lévai D. Specify the parameters of unsaturated soil (in Hungarian) Student Research, Department of Civil Engineering, Budapest University of Technology and Economics, 2013/2014/I.

[17] van Genuchten, M. Th. A closed-form equation for predicting the hydraulic conductivity of unsaturated soils, J Soil Sci Soc Am, Vol. 44, No. 5, 1980, pp. 892-898.

[18] Šimůnek J., Šejna M. Hydrus user manual and technical manual, Version 2, PC-Progress, Prague, Czech Republic, January 2011.

[19] Kozma Zs., Ács T., Koncsos L. Hydrological modeling of the unsaturated zone Evaluation of uncertainties related to the FAO soil classification system, Pollack Periodica, Vol. 8, No. 3, 2013, pp. 163-174.

[20] Mualem Y. A new model for predicting the hydraulic conductivity of unsaturated porous media, Water Resources Research, Vol. 12, 1976, 513-522.

[21] Galli L. Excavation dewatering designing and calculation (in Hungarian) Müszaki Könyvkiadó, Budapest, 1987. 